\title{
Quercetin Administration After Spinal Cord Trauma Changes S-100ß Levels
}

\author{
E. Schültke, R.W. Griebel, B.H.J. Juurlink
}

\begin{abstract}
Background: It has been shown previously that S-100 $\beta$ levels in serum correspond with the severity of central nervous system (CNS) trauma. It also has been suggested that S-100 $\beta$ in CNS tissue is involved in neuroprotection and neuroregeneration. We have previously shown that administration of quercetin results in improved motor function in an animal model of spinal cord trauma. Methods: Mid-thoracic spinal cord compression injury was produced in adult male Wistar rats. Serum and tissue samples were acquired from quercetin-treated animals $(25 \mu \mathrm{mol} / \mathrm{kg})$ and saline controls at 6,12 and 24 hours after the trauma. S-100 $\beta$ levels were measured using a luminometric assay in the damaged tissue and in the serum of the animals. Results: The increase in serum S-100 $\beta$ levels seen in saline controls after spinal cord trauma was ameliorated in the quercetin-treated animals at all time points, although the difference to saline controls became statistically significant only at $24 \mathrm{hrs}$ after the trauma. Compared to tissue S-100 $\beta$ levels in healthy animals, values were significantly decreased in saline controls at all three time points, while they were decreased at 6 hrs and increased at both 12 and 24 hrs in quercetin-treated animals. At all three time points tissue S-100 $\beta$ levels were significantly higher in quercetin-treated animals than in saline controls. Conclusions: Administration of quercetin results in modification of S-100 $\beta$ levels in the setting of experimental spinal cord trauma. The kinetic patterns of the S-100 $\beta$ fluctuations in serum and tissue suggest that post-traumatic administration of quercetin decreases the extent of CNS injury.
\end{abstract}

RÉSUMÉ: L'administration de quercétine après un traumatisme à la moelle épinière modifie les niveaux de $\mathrm{S}-100 \beta$. Contexte : Des travaux antérieurs ont démontré que les niveaux de $\mathrm{S}-100 \beta$ du sérum correspondent à la sévérité du traumatisme au niveau du système nerveux central (SNC) et il est possible que le S-100 $\beta$ joue un rôle dans la neuroprotection et la neurorégénération du SNC. Nous avons démontré antérieurement que l'administration de quercétine améliore la fonction motrice chez un modèle animal de traumatisme de la moelle épinière. Méthodes : Des rats Wistar mâles adultes ont été soumis à un traumatisme par compression de la moelle épinière au niveau thoracique moyen. Des échantillons de sérum et de tissus ont été prélevés chez des animaux traités par la quercétine $(25 \mu \mathrm{mol} / \mathrm{kg})$ et chez des animaux témoins qui ont reçu du salin 6 , 12 et 24 heures après le traumatisme. Les niveaux de S-100 $\beta$ dans le tissu lésé et dans le sérum des animaux ont été mesurés au moyen d'une épreuve luminométrique. Résultats : Au moment de tous les prélèvements, l'augmentation du niveau de S-100 $\beta$ observée chez les témoins après un traumatisme à la moelle épinière était plus faible que chez les animaux traités par la quercétine, bien que la différence par rapport aux témoins qui ont reçu du salin n'ait été significative au point de vue statistique que lors du prélèvement fait 24 heures après le traumatisme. Les valeurs étaient significativement plus faibles chez les témoins traités par le salin au moment de chacun des trois prélèvements et ils étaient diminués lors du prélèvement fait 6 heures après le traumatisme et augmentés lors de ceux faits 12 et 24 heures après chez les animaux traités par la quercétine par rapport aux niveaux de S-100 $\beta$ chez des animaux en santé. Les niveaux de S-100 $\beta$ étaient significativement plus élevés dans les tissus des animaux traités par la quercétine lors de chacun des trois prélèvements que chez les témoins qui ont reçu du salin. Conclusions : L'administration de quercétine a produit des modifications des niveaux de $\mathrm{S}-100 \beta$ après un traumatisme expérimental de la moelle épinière. La cinétique des fluctuations du S-100 $\beta$ dans le sérum et le tissu suggère que l'administration post-traumatique de quercétine diminue l'ampleur de la lésion du SNC.

Can. J. Neurol. Sci. 2010; 37: 223-228

S-100 $\beta$, a small monomer of the calcium-binding S-100 protein family with a molecular weight of about $10 \mathrm{kDa}$, has been found in both astrocytes and oligodendrocytes. ${ }^{1}$ Being present throughout the cytosol and as components of cytoskeleton and membranes; it has been suggested that S-100 $\beta$ is involved in guiding the progression of cells through the cell cycle. ${ }^{2}$ With a little over one and a half hours, S-100 $\beta$ has a relatively short half life, which makes it a good candidate for assessment in emergency situations like central nervous system (CNS) trauma. ${ }^{3}$ The results of studies conducted by a number of authors have shown that serum levels of S-100 $\beta$ can be used as predictor for the extent of tissue injury in the CNS. Most of these studies have been conducted in adult and paediatric patients who had suffered head trauma of varying degrees. ${ }^{4-9}$ Other studies have found a positive correlation between serum S-100 $\beta$ levels and functional outcome in patients after hypoxic or traumatic CNS injury. ${ }^{10-15}$

From the Departments of Anatomy \& Cell Biology (ES, BHJJ) and Surgery, Division of Neurosurgery (ES, RWG), University of Saskatchewan, Saskatoon, SK, Canada; Department of Stereotactic and Functional Neurosurgery (ES), University of Freiburg, Germany; College of Medicine (BHJ), Alfaisal University, Riyadh, Kingdom of Saudi Arabia.

Received May 26, 2009. Final Revisions Submitted September 24, 2009. Correspondence to: Elisabeth Schültke, A302 Health Sciences Building, College of Medicine, University of Saskatchewan, 107 Wiggins Road, Saskatoon, Saskatchewan, S7N 5E5, Canada. 
Studies relating serum S-100 $\beta$ levels to spinal cord injury (SCI) have been mainly focused on ischemic injury caused by temporary clamping of the aorta during the repair of aortic aneurysms. ${ }^{16-18}$ It was shown that serum S-100 $\beta$ levels were significantly increased in patients with post-surgical functional impairment from spinal cord ischemia.

More recently, it has been shown in animal models of spinal cord injury that changes in serum S-100 $\beta$ levels are also detectable after spinal cord trauma. ${ }^{19-21}$ We had shown previously that administration of the flavonoid quercetin in animal models of moderate fluid percussion injury and spinal cord compression injury resulted in improved post-traumatic function. ${ }^{22,23}$ We now have designed an experiment with the aim to investigate whether this later decrease in functional deficit is reflected in S-100ß levels early after SCI.

\section{Materials And Methods}

Animal model: A total of 21 adult male Wistar rats, about 11 weeks of age (286 -310 g), were used for these experiments. Of these, 18 animals were submitted to spinal cord compression injury and three animals served as non-injured healthy controls. Spinal cord injury was induced using the model originally developed by Rivlin and Tator. ${ }^{24}$ Briefly, the back of the animals was shaved and the skin was disinfected with chlorhexidine and $70 \%$ alcohol. Anaesthesia was induced with $3 \%$ and maintained with $1.5-2 \%$ halothane in 1.5 litre oxygen per minute. Each animal received one dose of $0.05 \mathrm{mg}$ Buprenorphine ${ }^{\circledR} / \mathrm{kg}$ s.c. before surgery and the 24 hour survivors received a second dose at 12 hours after surgery. A vertical midline incision of the skin was performed over the spinous processes of Th5 to Th7 and the muscles were detached from the Th6 and Th7 laminae. A laminectomy was performed at the Th6/7 level and a 50g force calibrated aneurysm clip (Kerr-Lougheed clip, Walsh Manufacturing, Oakville, Ontario) was applied to the thoracic cord at level Th7 for five seconds. Muscles and skin were sutured, after which the animals were allowed to recover. The closing force of the clip was not re-assessed at the end of this particular experiment, but after a subsequent experiment. From that measurement, we can extrapolate a weakening of the spring force of about $6.4 \%$ throughout the experiments in the series described in this paper. Our experiments were performed on two subsequent days. On the first day, animals were assigned randomly to either the 12 hours or 24 hours-groups, while the animals of the six hours-group underwent surgery on the following day. Half of the injured animals were chosen randomly to receive intraperitoneal (i.p.) injections of $25 \mu$ mol quercetin / $\mathrm{kg}$ rat, starting one hour after the injury. Animals surviving 12 or 24 hours received a second dose of each quercetin and Buprenorphine ${ }^{\circledR}$ at 11 hours after the injury and animals surviving for 24 hours received a third dose of quercetin at 23 hours after the trauma. The other nine animals received equal volumes of normal saline i.p., saline being used as carrier for quercetin. At 6,12 and 24 hours after the injury, three quercetintreated animals and three saline controls were sacrificed by exsanguination under a Halothane overdose. Venous blood was collected in heparinized test tubes with the animals under general anaesthesia immediately before death. The blood was centrifuged after which the serum was collected and stored at $80^{\circ} \mathrm{C}$ until analysis was performed. Raabe and colleagues have shown that freezing samples at $-80{ }^{\circ} \mathrm{C}$ does not alter the measured S100-beta concentrations in the samples. ${ }^{25} \mathrm{~A}$ generous spine-muscle block, including about three spinal levels above and below the laminectomy site, was removed from the body of each animal. While repeatedly dousing with liquid nitrogen, a serial laminectomy was performed to expose the spinal cord for collection of the injury segment (Figure 1). The injury segments, identified by the linear mark left by the clip application, were flash frozen in liquid nitrogen and stored in the freezer at $-80^{\circ} \mathrm{C}$ until analysis was performed. Our animals were housed and cared for in a temperature-regulated animal facility exposed to a 12 hour light/dark cycle and experiments were performed in accordance with the guidelines of the Canadian Council on Animal Care, as approved by the University of Saskatchewan Animal Care Committee.

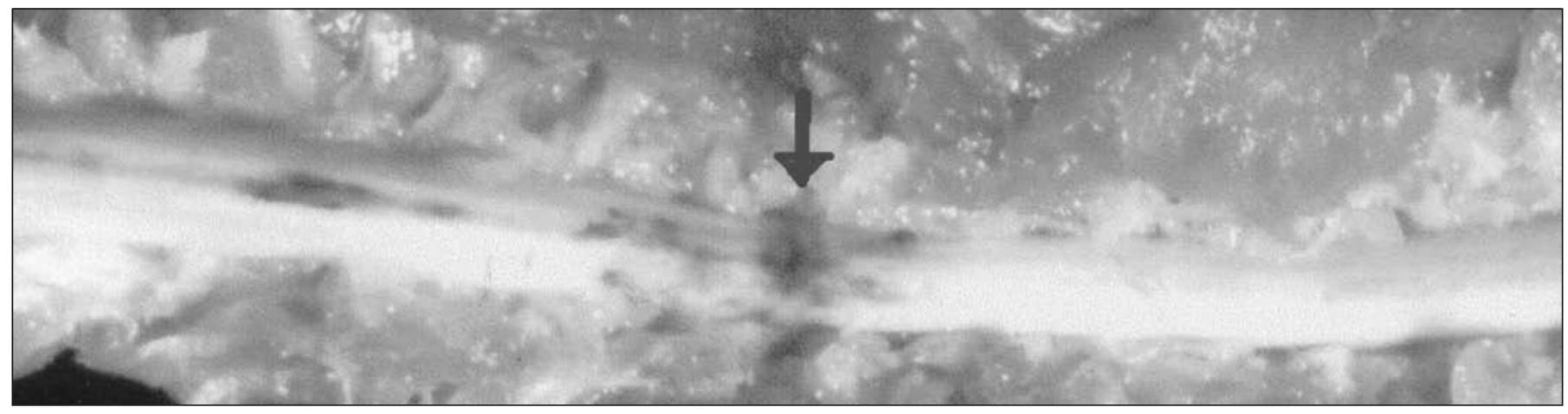

Figure 1: Spinal cord of adult male Wistar rat at 12 hrs after SCI produced by closing a Kerr-Lougheed aneurysm clip calibrated to $50 \mathrm{~g}$ around the spinal cord for five seconds. A spine-muscle block has been removed from the body of the dead animal, While repeatedly dousing with liquid nitrogen, a serial laminectomy has been performed to expose the spinal cord for collection of the injury segment. The arrow head points at the site of injury. 
Luminometric S-100ß assay: An in-vitro immunoassay specific for quantitative determination of the $S-100 \beta$ protein subunit (LIA-mat ${ }^{\circledR S}$ Sangtec $(100$ kits, AB Sangtec Medical, Bromma, Sweden) was used for analysis. Briefly, $100 \mu \mathrm{l}$ of diluent and $100 \mu \mathrm{l}$ of sample were added to each test tube containing a solid-phase antibody and incubated at room temperature. One hour later, the samples were washed three times, using the washing solution provided with the kit, and analyzed in a luminometer with two programmable injectors and automatic readout (Berthold Detection Systems, Germany). The injectors added $300 \mu 1$ alkaline peroxide solution and $300 \mu 1$ catalyst solution to each sample. The measurement period was five seconds. Samples were run in duplicate and the mean values were used for further analysis. The detection limit for this monoclonal antibody assay directed against the $\beta$-chain of the S100 molecule is $0.02 \mu \mathrm{g} /$ litre.

Frozen spinal cord segments were individually ground into powder form while suspended in liquid nitrogen, using a MikroDismembranator S (B. Braun Biotech International, Melsungen, Germany). Out of each powdered sample, $5 \mathrm{mg}$ were suspended in $0.5 \mathrm{ml}$ of $50 \mathrm{mM} \mathrm{HTAB}$ (phosphate buffer, $\mathrm{pH} \mathrm{6}$ ) on ice and sonicated twice for three seconds and once for five seconds. The sonicated homogenates were centrifuged for 15 minutes at $13,000 \mathrm{rpm}$ and $4^{\circ} \mathrm{C}$. The supernatant of each sample was diluted 1:40 in normal saline. The tissue contents were calculated in $\mu \mathrm{g}$ S-100 $\beta$ / g spinal cord tissue. Luminometric determination of S$100 \beta$ serum levels was performed in the Department of Anatomy and Cell Biology at the University of Saskatchewan. The MannWhitney test (non-parametric t-test assuming non-Gaussian distribution) was used for data analysis.

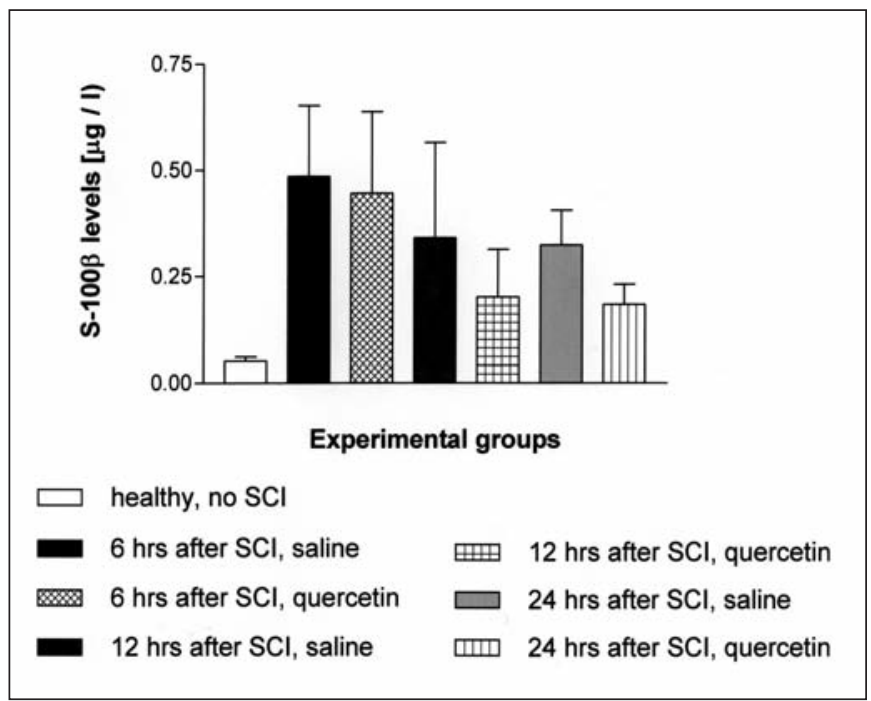

Figure 2: S-100 $\beta$ levels in the serum of adult male Wistar rats at 6, 12 and 24 hours after spinal cord compression injury (means $\pm S D, n=3$ ). A significant increase in both quercetin-treated animals and saline controls was observed at all three time points. The difference between quercetintreated animals and saline controls became more pronounced with increasing time after SCI and was statistically significant at 24 hours.

\section{RESULTS}

S-100及 level in serum: The mean value for serum S-100 $\beta$ levels in healthy, non-injured animals was $0.051 \mu \mathrm{g} / 1$ ( $\mathrm{SD} \pm$ $0.009)$. A significant increase of $S-100 \beta$ levels was seen at all three time points in both quercetin-treated animals ( $p=0.009$ at 6 hours, $\mathrm{p}=0.009$ at 12 hours and $\mathrm{p}=0.016$ at 24 hours) and saline controls ( $\mathrm{p}=0.009$ at 6 hours, $\mathrm{p}=0.009$ at 12 hours and $\mathrm{p}=0.016$ at 24 hours), compared to healthy animals. While the increase was only insignificantly smaller in quercetin-treated animals than in saline controls at 6 hours after SCI ( $\mathrm{p}=0.589)$, at 12 hours after SCI the difference between quercetin-treated animals and untreated controls was considerably smaller, albeit not statistically significant $(\mathrm{p}=0.24)$. At 24 hours after $\mathrm{SCI}$, the increase in S-100 $\beta$ serum values was significantly smaller in quercetin-treated animals than in saline controls $(\mathrm{p}=0.008)$. The increase of serum S-100 $\beta$ was highest at $6 \mathrm{hrs}$ after SCI and then continually decreased. This kinetic agrees with the observations made in a rat model of SCI by other researchers. ${ }^{16}$ For the saline controls, group means were $0.486 \mu \mathrm{g} / 1(\mathrm{SD} \pm 0.068)$ at 6 hours, $0.342 \mu \mathrm{g} / 1(\mathrm{SD} \pm 0.092)$ at 12 hours and $0.324 \mu \mathrm{g} / 1$ ( $\mathrm{SD} \pm$ 0.082 ) at 24 hours after SCI. The mean values for the quercetintreated animals were $0.446 \mu \mathrm{g} / 1(\mathrm{SD} \pm 0.192)$ at 6 hours, $0.202 \mu \mathrm{g} / 1(\mathrm{SD} \pm 0.112)$ at 12 hours and $0.184 \mu \mathrm{g} / 1(\mathrm{SD} \pm$ 0.048 ) at 24 hours after SCI (Figure 2).

S-100及 level in spinal cord tissue: The mean value for S$100 \beta$ in healthy spinal cord tissue was $3.34 \mu \mathrm{g} / \mathrm{g}$ spinal cord $(\mathrm{SD} \pm 1.56)$. At 6 hours after $\mathrm{SCI}$, the mean values for $\mathrm{S}-100 \beta$ in tissue at the site of injury were $0.87 \mu \mathrm{g} / \mathrm{g}(\mathrm{SD} \pm 0.47)$ for saline controls and $1.7 \mu \mathrm{g} / \mathrm{g}(\mathrm{SD} \pm 1.1)$ for quercetin-treated animals

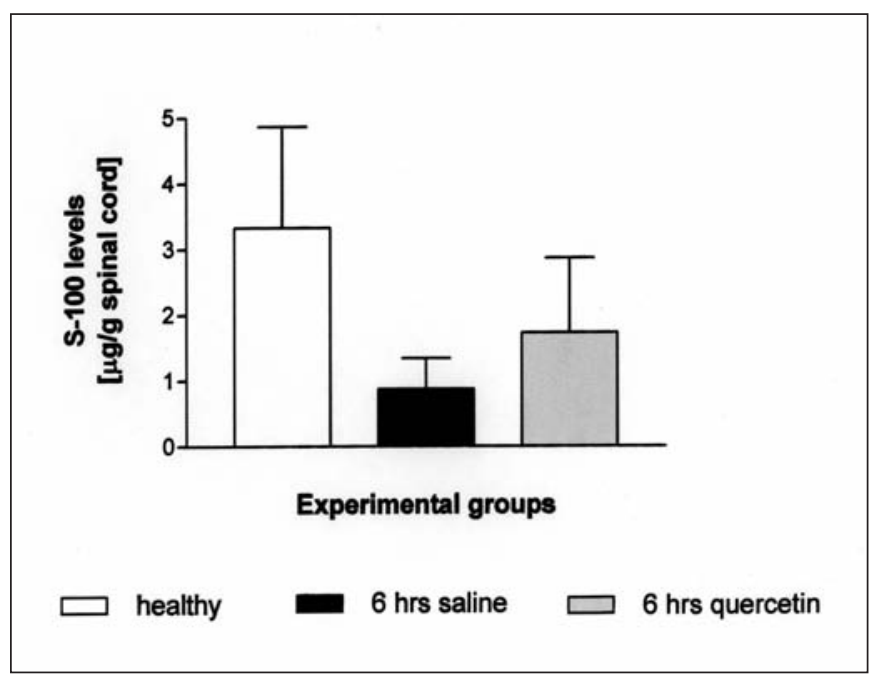

Figure 3: S-100 $\beta$ levels in tissue at the site of injury at 6 hours after spinal cord compression injury (means $\pm S D, n=3$ per group); adult male Wistar rat. A considerable decrease of S-100 $\beta$ in the tissue at the site of injury was seen in both quercetin-treated animals and saline controls, compared to healthy spinal cord tissue. The decrease was less pronounced in quercetin-treated animals, although the difference was not statistically significant $(p=0.4)$. 


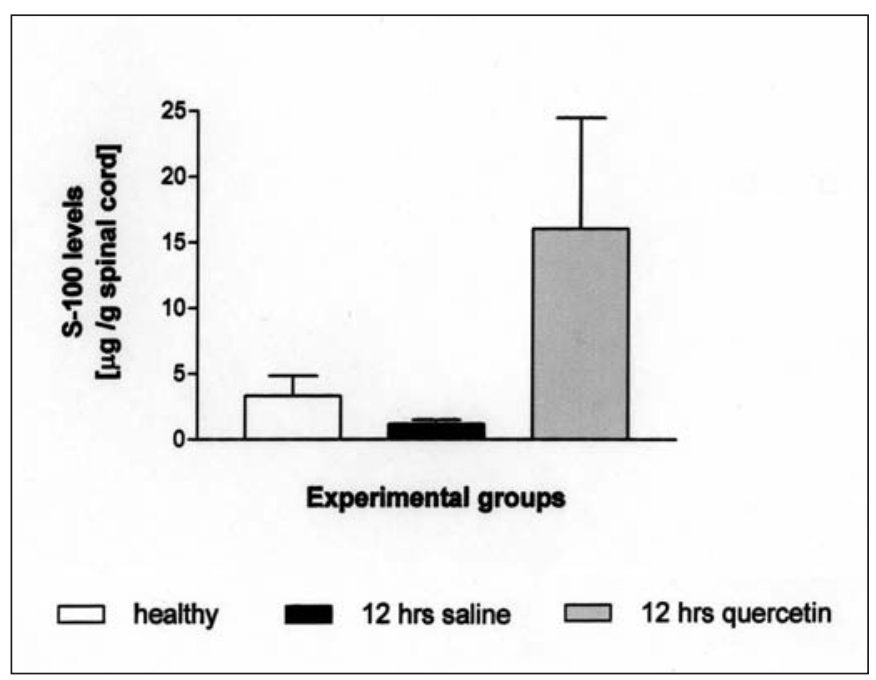

Figure 4: S-100 $\beta$ levels in tissue at the site of injury at 12 hours after $S C I$ (means $\pm S D, n=3$ per group); adult male Wistar rat. Compared to the healthy controls, there is still a considerable, albeit not statistically significant decrease of $S-100 \beta$ at the site of injury in saline controls (0.114), but a significant increase was seen in the tissue of querctintreated animals $(p=0.0043)$.

(Figure 3). Although there was a considerable decrease of S$100 \beta$ levels in both quercetin-treated animals and saline controls, compared to healthy animals, neither was statistically significant $(\mathrm{p}=0.167$ for saline and $\mathrm{p}=0.168$ for quercetin). Although the decrease was less noticeable in quercetin-treated animals than in saline controls, this was not statistically significant $(\mathrm{p}=0.4)$.

As illustrated in Figure 4, at 12 hours after SCI, the mean values for $\mathrm{S}-100 \beta$ in tissue at the site of injury were $16.06 \mu \mathrm{g} / \mathrm{g}$ $(\mathrm{SD} \pm 8.4)$ for quercetin-treated animals and $1.18 \mu \mathrm{g} / \mathrm{g}(\mathrm{SD} \pm$ 0.32 ) for saline controls (i.e. the $S 100 \beta$ values for saline controls were lower than those for healthy controls). There was a strong albeit not statistically significant difference between $100 \beta$ values in the spinal cord tissue of healthy animals and saline controls $(\mathrm{p}=0.114)$. The differences were statistically significant between the tissue of healthy and quercetin-treated animals $(\mathrm{p}=0.0043)$ and between quercetin-treated animals and saline controls $(\mathrm{p}=0.0095)$.

Figure 5 illustrates the distribution of tissue S-100 $\beta$ levels at 24 hours after SCI. The mean values for S-100 $\beta$ at the site of injury were $9.99 \mu \mathrm{g} / \mathrm{g}(\mathrm{SD} \pm 2.46)$ for quercetin-treated animals and $2.85 \mu \mathrm{g} / \mathrm{g}(\mathrm{SD} \pm 0.66)$ for saline controls. At 24 hours after SCI, the difference between $100 \beta$ values in the spinal cord tissue of healthy animals and saline controls was much less pronounced $(p=0.171)$ than at 12 hours. The differences between the tissue of healthy and quercetin-treated animals $(\mathrm{p}=0.0095)$ and between quercetin-treated animals and saline controls $(\mathrm{p}=0.029)$ were statistically significant.

\section{Discussion:}

Initially, the drastic increase of S-100 $\beta$ levels in spinal cords of quercetin-treated spinal injured animals was quite surprising

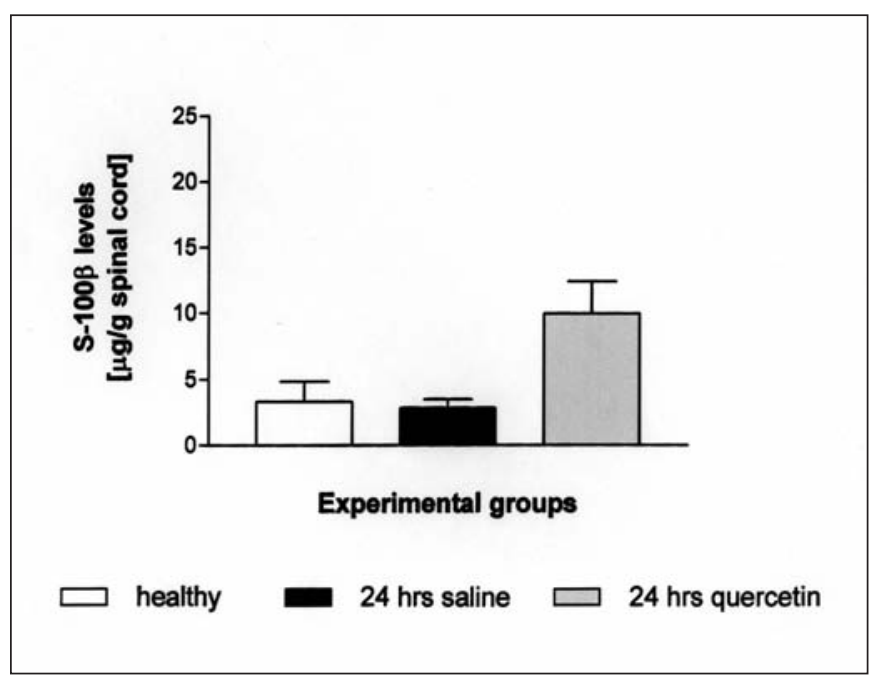

Figure 5: S-100 $\beta$ levels in tissue at the site of injury at 24 hrs after SCI (means $\pm S D, n=3$ per group); adult male Wistar rat. $S$ - $100 \beta$ levels at the injury site of saline controls have further increased again and are now close to normal. S-100 $\beta$ levels at the injury site of quercetin-treated animals have dropped from the peak at 12 hours after SCI but are still significantly higher than in healthy spinal cord ( $p=0.0095)$. to us, since we expected kinetics similar to those seen in serum. On searching the literature, however, we found that, in culture, S-100 $\beta$ promotes rapid re-assembly and / or stabilization of microtubules after disruption of the cytoskeletal system. ${ }^{26}$ In the peripheral nervous system of rats, S-100 $\beta$ has been found to prevent motor neuron death and stimulate repair., ${ }^{27,28}$ Thus, contrary to serum values, in tissue an increase in S-100 $\beta$ values is likely the desired hallmark of activated preservation and repair mechanisms. The decrease of S- $100 \beta$ levels in the tissue of the saline controls, compared to the tissue of healthy animals, might reflect a net loss of S-100 $\beta$ from the tissue. The S-100 $\beta$ units lost from the tissue are likely those that cause the S-100 $\beta$ increase in the serum, where they then are used correctly as indicator for the extent of tissue damage present.

Liu and colleagues have shown that four hours after one single intraperitoneal injection of quercetin the levels of free malondialdehyde and free iron were significantly lower than in injured saline controls, i.e. the oxidative stress potential in the tissue was significantly reduced. ${ }^{29}$ Although those authors do not report any neurological improvement after quercetinadministration, this might be due to only single rather than repeated administration of the compound. The fact that over time the S-100 $\beta$ tissue levels in quercetin-treated animals eclipse the values of normal tissue might be due to an induction of repair processes caused by quercetin. That would agree with published observations in another animal study, where the degree to which the animals recovered motor function spontaneously after spinal cord compression injury was found to be related to an increase above healthy values in tissue S-100 $\beta$ levels at and beyond Day 3 after SCI. ${ }^{17}$ In our experiment, measuring S- $100 \beta$ during a very early stage after SCI, the group means of tissue S-100 $\beta$ levels 
were higher in quercetin-treated animals than those in saline controls at all time points. Where $S-100 \beta$ levels in saline controls had not even recovered yet to those of healthy animals, S-100 $\beta$ levels in the tissue of quercetin-treated animals already eclipsed those of healthy animals.

Although our experimental groups were quite small, we believe that the fact that there is consistency throughout all time points suggests that we are looking at a true protective effect of quercetin, reflected in higher S-100 $\beta$ levels in the tissue at the site of injury and lower serum S-100 $\beta$ levels, compared to saline controls. This assumption is supported by the observation that, throughout our study, individual animals with very high tissue levels always had very low S-100 $\beta$ serum levels. Although the nature of our study did not allow observations with regard to functional recovery, we have shown previously that quercetintreated animals retain or recover function better than saline controls in both spinal cord trauma and head trauma. ${ }^{22,23}$ In the head trauma study, compound action potentials at the site of injury were much better preserved in animals who had received quercetin at exactly the same dose and schedule as the animals in our S-100 $\beta$ study, compared to saline controls, at 24 hours after the trauma ${ }^{23}$.

Other authors have hypothesized that the rapid fall of serum S-100 $\beta$ levels after CNS trauma could be due to either stabilization of the initially disrupted blood brain barrier or to cessation of $S-100 \beta$ production. ${ }^{30}$ In our study we have seen that over the 24 hours observation period, S-100 $\beta$ levels in serum were decreasing continuously after the initial rise while, after an initial drop, S-100 $\beta$ tissue levels were rising. This refutes the idea of a cessation in $\mathrm{S}-100 \beta$ production. Given the results of our study, we believe that stabilization of the blood brain barrier is a much more likely explanation for falling serum S-100 $\beta$ levels after CNS trauma.

\section{Conclusions}

We found that both S-100 $\beta$ levels in serum and in tissue from the site of injury are a good indicator for the protective and possibly regenerative capacities of quercetin in our animal model of spinal cord compression injury. For long-term in vivo experiments as well as for clinical studies tissue analysis is, of course, out of the question. However, the overview over the kinetics of S-100 $\beta$ values in tissue and serum during the first 24 hours after the trauma permits a good explanation of how the increased serum values, which have been shown by a number of clinical researchers to be predictive of the extent of injury, might be caused.

\section{ACKNOWLEDGMENTS}

The authors thank Arlene Drimmie for help with the animal care. Our work was supported by grants from the Christopher Reeve Paralysis Foundation to E. Schültke and B. Juurlink.

\section{REFERENCES}

1. Steiner J, Bernstein HG, Bielau H, Berndt A, Brisch R, Mawrin C, et al. Evidence for a wide extra-astrocytic distribution of S100B in human brain. BMC Neurosci. 2007;8:2.

2. Adami C, Sorci G, Blasi E, Agneletti AL, Bistoni F, Donato R. S100B expression in and effects on microglia. Glia. 2001;33(2): $131-42$.
3. Townend W, Dibble C, Abid K, Vail A, Sherwood R, Lecky F. Rapid elimination of protein S-100B from serum after minor head trauma. J Neurotrauma. 2006;23(2):149-55.

4. Raabe A, Grolms C, Keller M, Döhnert J, Sorge O, Seifert V. Correlation of computed tomography findings and serum brain damage markers following severe head injury. Acta Neurochir. (Wien) 1998;140(8):791-2.

5. Ingebrigtsen T, Waterloo K, Jacobsen EA, Langbakk B, Romner B. Traumatic brain damage in minor head injury: relation of serum S-100 protein measurements to magnetic resonance imaging and neurobehavioral outcome. Neurosurgery. 1999;45(3):475-6.

6. Woertgen C, Rothoerl RD, Metz C, Brawanski A. Comparison of clinical, radiologic and serum marker as prognostic factors after severe head injury. J Trauma. 1999;47(6):1126-30.

7. Herrmann M, Jost S, Kutz S, Ebert AD, Kratz T, Wunderlich MT, et al. Temporal profile of release of neurobiochemical markers of brain damage after traumatic brain injury is associated with intracranial pathology as demonstrated in cranial computerized tomography. J Neurotrauma. 2000;17(2):113-22.

8. Romner B, Ingebrigtsen T, Kongstad P, Borgesen SE. Traumatic brain damage: serum S-100 protein measurements related to neuroradiolagical findings. J. Neurotrauma. 2000;17(8):641-7.

9. Poli-de-Figueiredo LF, Biberthaler P, Simao Filho C, Hauser C, Mutschler W, Jochum M. Measurement of S-100B for risk classification of victims sustaining minor head injury-first pilot study in Brazil. Clinics. 2006;61(1):41-6.

10. Thorngren-Jerneck K, Ohlsson T, Sandell A, Erlandsson K, Strand SE, Ryding E, et al. Cerebral glucose metabolism measured by positron emission tomography in term newborn infants with hypoxic ischemic encephalopathy. Pediatr Res. 2001;49(4): 495-501.

11. Raabe A, Grolms C, Sorge O, Zimmermann M, Seifert V. Serum S100 protein in severe head injury. Neurosurgery. 1999;45(3): 477-83.

12. Raabe A, Grolms C, Seifert V. Serum markers of brain damage and outcome prediction in patients after severe head injury. Br $\mathrm{J}$ Neurosurg. 1999;13(1):56-9.

13. Raabe A, Seifert V. Fatal secondary increase in serum S-100 $\beta$ protein after severe head injury. Report of three cases. J Neurosurg. 1999;91(5):875-7.

14. Rothoerl RD, Woertgen C, Holzschuh M, Metz C, Brawanski A. S100 serum levels after minor and major head injury. J Trauma. 1998;45(4):765-7.

15. Woertgen C, Rothoerl RD, Holzschuh M, Metz C, Brawanski A. Comparison of serial S-100 and NSE serum measurements after severe head injury. Acta Neurochir. (Wien) 1997;139(12): 1161-5.

16. Khaladj N, Teebken OE, Hagl C, Wilhelmi MH, Tschan C, Weissenborn K, et al. The role of cerebrospinal fluid S100 and lactate to predict clinically evident spinal cord ischaemia in thoraco-abdominal aortic surgery. Eur J Vasc Endovasc Surg. 2008;36(1):11-9.

17. Kunihara T, Shiiya N, Yasuda K. Changes in S100beta protein levels in cerebrospinal fluid after thoracoabdominal aortic operations. J Thorac Cardiovasc Surg. 2001;122(5):1019-20.

18. van Dongen EP, Ter Beek HT, Boezeman EH, Schepens MA, Langemeijer HJ, Aarts LP. Normal serum concentrations of S100 protein and changes in cerebrospinal fluid concentrations of S-100 protein during and after thoracoabdominal aortic aneurysm surgery: Is S-100 protein a biochemical marker of clinical value in detecting spinal cord ischemia? J Vasc Surg. 1998;27(2):344-6.

19. Cao F, Yang XF, Liu WG, Hu WW, Li G, Zheng XJ, et al. Elevation of neuron-specific enolase and S-100beta protein level in experimental acute spinal cord injury. J Clin Neurosci. 2008;15 (5):541-4.

20. do Carmo Cunha J, de Freitas Azevedo Levy B, de Luca BA, de Andrade MS, Gomide VC, Chadi G. Responses of reactive astrocytes containing S100beta protein and fibroblast growth factor-2 in the border and in the adjacent preserved tissue after a contusion injury of the spinal cord in rats: implications for wound repair and neuroregeneration. Wound Repair Regen. 2007;15(1):134-46. 
21. Loy DN, Sroufe AE, Pelt JL, Burke DA, Cao QL, Talbott JF, et al. Serum biomarkers for experimental acute spinal cord injury: rapid elevation of neuron-specific enolase and S-100beta. Neurosurgery. 2005;56(2):391-7.

22. Schültke E, Kendall EJ, Kamencic H, Ghong Z, Griebel RW, Juurlink BHJ. MRI supported dose determination: an animal study on the efficacy of quercetin dihydrate in acute spinal cord injury. J Neurotrauma. 2003;20(6):583-91.

23. Schültke E, Kamencic H, Zhao M, Tian GF, Baker AJ, Griebel RW, et al. Neuroprotection following fluid percussion brain trauma: A pilot study using quercetin. J Neurotrauma. 2005;22(12):1475-84.

24. Rivlin AS, Tator CH. Effect of duration of acute spinal cord compression in a new acute injury model in the rat. Surg Neurol. 1978;10:38-43.

25. Raabe A, Kopetsch O, Gross U, Zimmermann M, Gebhart P. Measurements of serum S-100B protein: effects of storage time and temperature on pre-analytical stability. Clin Chem Lab Med. 2003;41(5):700-3.
26. Nishi M, Kawata M, Azmitia EC. S100beta promotes the extension of microtubule associated protein2 (MAP2)-immunoreactive neurites retracted after colchicine treatment in rat spinal cord culture. Neurosci Lett. 1997;229(3):212-4.

27. Iwasaki Y, Shiojima T, Kinoshita M. S100 beta prevents the death of motor neurons in newborn rats after sciatic nerve section. $\mathrm{J}$ Neurol Sci. 1997;151(1):7-12.

28. Haglid KG, Yang Q, Hamberger A, Bergman S, Widerberg A, Danielsen N. S-100beta stimulates neurite outgrowth in the rat sciatic nerve grafted with acellular muscle transplants. Brain Res. 1997;753(2):196-201.

29. Liu JB, Tang TS, Yang HL. Antioxidation of quercetin against spinal cord injury in rats. Clin J Trauma. 2006;9(5):303-7.

30. Jackson RG, Samra GS, Radcliffe J, Clark GH, Price CP. The early fall in levels of S-100 beta in traumatic brain injury. Clin Chem Lab Med. 2000;38(11):1165-7. 